\title{
Protein, amino acid and energy requirements of weanling foals and yearlings
}

\author{
Markku T. Saastamoinen \\ Agricultural Research Centre, Equine Research, Ypäjä, Finland
}

\begin{abstract}
Summary
Weanling foals are sensitive to the quality of dietary protein, i.e. amino acid supply. Lysine and threonine have been indicated as the two first-limiting amino acids for growth, but data on other amino acids are inadequate for establishing any accurate recommendations. Dietary protein quality has been reported to influence the amino acid profile of serum, and the blood amino acid concentrations and amino acid intakes reported in certain studies may have some value as guidelines in determining the amino acid requirements of growing horses. The energy requirements of weanling foals depend on age, growth rate and proportion of the utilized growth potential. Furthermore, the requirements for growth are influenced, e.g., by the ambient temperature and the type of energy source fed to foals.
\end{abstract}

keywords: foal, horse, energy, nutrition, protein

\begin{abstract}
Eiweiß-, Aminosäuren- und Energiebedarf von Absetzfohlen und Jährlingen
Absetzfohlen sind sensibel gegenüber Veränderungen in der Qualität des Futterproteins, d.h. der Aminosäurenzufuhr. Lysin und Threonin sind als die beiden erstlimitierenden Aminosäuren für wachsende Pferde beschrieben worden; die Daten für die übrigen Aminosäuren hingegen lassen eine präzise Versorgungsempfehlung nicht zu. Andererseits beeinflußt die Qualität des aufgenommenen Rohproteins das Aminosäurenmuster im Blutserum; demnach geben Daten zu den Aminosäuren im Blut und der Aminosäureaufnahme aus verschiedenen Untersuchungen Anhaltspunkte zur Bestimmung des Aminosäurenbedarfs wachsender Pferde. Der Energiebedarf von Absetzfohlen hängt von Alter, der Körpermasseentwicklung und ausgenutzten Wachtumskapazität ab. Weitere Einflußfaktoren für den Bedarf von Jungpferden sind Umgebungstemperatur und Art der verwendeten Energieträger.
\end{abstract}

Schlüsselwörter: Energie, Ernährung, Fohlen, Pferde, Protein

\section{Introduction}

The growth rate of foals is influenced by diet, predominantly by energy and protein. The growth of foal during its first year is very rapid. At the age of 12 months, a horse has achieved about $65 \%$ of its adult weight and more than $90 \%$ of its adult height. At 18 months of age, the weight of yearling is about $77 \%$ and the height $95 \%$ of the adult measurements. Thus, the proper nutrition of weanlings and yearlings to ensure normal growth and development sets great demands on breeders.

Several studies conducted during the past years have dealt with the effect of nutrition on the growth and development of foals. The present paper reviews several of these studies and recommendations concerning the protein, amino acid and energy requirements of weanlings and yearlings.

\section{Protein}

Pre-caecal digestion has a major role in protein digestion in horses, the small intestine being the primary site of protein digestion and amino acid absorption. Dietary protein which escapes digestion in the small intestine and reaches the hindgut is degraded to ammonia. Consequently, protein digestion and absorption in the horse closely resembles these functions in pigs, dogs and chicken (Reitnour et al. 1970).
In their study, Reitnour et al. (1970) concluded that residual and endogenous nitrogen reaching the caecum can be modified by microbial synthesis. Microorganisms of the lower digestive tract may, therefore, improve the biological value of low-quality protein in horses with a mature intestinal microfloral ecosystem, i.e. adult horses (Slade et al. 1970; Kennedy and Hershberger 1974). Thus, young growing horses require high-quality protein, and several studies show that they are sensitive to protein level and quality, responding to indispensable amino acid supplementation with improved growth. Godbee and Slade (1981) reported that urea added to a diet that is marginally adequate in protein improves the weight gain of yearlings and twoyear-olds, but not of weanlings.

Only a small proportion of the amino acids present in microbial protein is made available for direct utilization and can be absorbed from the large intestine. In addition, dietary factors such as the content of nondigestible but fermentable carbohydrate may affect bacterial protein synthesis in the large intestine, thereby altering the apperent crude protein digestiblity.

Dietary fat supplementation has been reported to result in improved ideal digestibility of amino acids and to have a protein-sparing effect in growing-finishing pigs (Imbeah and Sauer 1991; Li and Sauer 1994). This may be due to delayed 
gastric emptying and slower rate of passage of the diet in the small intestine ( $L i$ and Saver 1994). Thus, it may account for the improved growth and feed efficiency resulting from fat supplementation reported in growing horses (Davison et al. 1991; Saastamoinen et al. 1994). Furthermore, enzyme specificity is an important determinant of apparent amino acid absorption in the small intestine. Glade and Sist (1990) reported that yeast culture may improve protein digestibility and amino acid balance in growing horses. Increased protein intake has also been reported to improve the apparent digestibility in horses (Reitnour and Salsbury 1976; Schryver et al. 1987).

It has been shown in several studies that the protein requirement of horses is smaller when they are given good-quality protein than when given poor-quality protein. Inclusion of the first-limiting amino acids in the diet may improve amino acid utilization through an improved amino acid balance (Smith and Scott 1965). Thus, when high-quality protein is added to the diet, proportinately more amino acids can be used for protein synthesis. It is likely that dietary protein and essential amino acid requirements will vary along with the composition of the diet and the quality of protein. Cereals which are normally fed to horses are deficient in several essential amino acids including lysine, threonine and tryptophan (Mello 1993). These critical amino acids are also the least digestible of all the essential amino acids, particularly in cereals. Imbalanced mixtures of amino acids further decrease the utilization of limiting amino acids and reduce food intake and growth (Mello 1993).

The protein requirements of foals are higher than those of other horses and depend on their growth rate and growth potential, as well as on the protein content of gain (Tab. 1). Also the maintenance requirements in growing horses is higher than in adult horses (Meyer 1983). Growth rate is regulated by the breed and by individual differences as well as the age and growth stage of the foal. Both growth rate and the protein content of gain decrease with age (Meyer 1983). Serum urea levels declined with age may suggest that protein requirements decrease after the age of 9-10 months (Saastamoinen et al. 1994), and studies have also shown that weanlings do not benefit from protein

Tab. 1: Protein content of foal's gain (Meyer 1983)

Eiweißgehalt im Zuwachs von Fohlen

\begin{tabular}{|c|c|}
\hline Age (months) & Protein $\mathrm{g} / \mathrm{kg}$ gain \\
\hline $3-6$ & 197 \\
\hline $7-12$ & 186 \\
\hline $13-18$ & 177 \\
\hline $19-24$ & 170 \\
\hline $25-36$ & 165 \\
\hline
\end{tabular}

supplementation after 8-10 months of age (Jordan and Myers 1972; Cymbaluk 1990a; Saastamoinen and Koskinen 1993).

Dietary crude protein contents of over $12 \%$, ranging between 12 and $16 \%$, are recommended, or are reported to result in the best growth in weanlings and yearlings (Hintz et al. 1971; Yoakam et al. 1978; Ott et al. 1981; Cymbaluk 1990a; Saastamoinen and Koskinen 1993; Saastamoinen et al. 1994; NRC 1989). Neither urinary calcium excertion nor calcium absorption was affected by protein intake (9-20\% CP) of weanling foals in the study by Schryver et al. (1987). The increment of protein content from 14 to $20 \%$ CP had neither beneficial nor harmful effects on growth. On the other hand, bone turnover was depressed and growth rate declined in foals fed a low-protein (9\% CP) diet, compared to foals fed 14 and $20 \%$ diets.

Excess dietary protein has been found to reduce the growth of growing ponies (Yoakam et al. 1978). This is obviously due to the fact that excess protein may cause additional energy costs due to extra heat increment because of the catabolism of the excess amino acids (Henry et al. 1992). An inrease in growth in response to an increasing dietary protein level can only occur when essential amino acids are the limiting nutrients for growth. The effect of dietary protein level on growth is generally confounded with the ammount of lysine in the diet.

The digestible crude protein (DCP) recommended in Finnish (FFT 1995), French (Martin-Rosset 1990) and German (DLG 1984) recommendations vary between approximately 450 and $500 \mathrm{~g} \mathrm{DCP}$ for weanlings (6-7-8-12 months of age; mature weight $500 \mathrm{~kg}$ ), and between 400 and $450 \mathrm{~g}$ for yearlings, assuming that the lysine level is as recommended. The recommended intakes by NRC (1989) are somewhat higher, assuming digestibility of crude protein to be $65-70 \%$. The recommended energy-to-protein ratio is about 0.13 and $0.16 \mathrm{MJ}$ DE/g DCP for weanlings and yearlings, respectively (DLG 1984; FFT 1995).

Exercise seems to help maintain the growth rate in young horses fed low-protein (6-8\% CP) diets, and regurlarly exercised growing horses may be given diets of somewhat lower protein concentrations than recommended (Orton et al. 1985). No amino acid intakes, however, were reported in their study.

\section{Amino acids}

The need for individual amino acids in foals is not well known. However, the following 10 indispensable amino acids are required for growth in the rat: arginine, histidine, isoleucine, leucine, lysine, methionine, phenylalanine, threonine, tryptophan and valine (McDonald et al. 1988). The list required by pigs is similar, with the exception of arginine and histidine. Lysine and threonine have been reported to be growth-limiting amino acids in weanlings and yearlings (e.g. Graham et al. 1994), and arginine in nurslings (Buffington et al. 1992).

Amino acids taken up from the blood after feed ingestion as well as those generated by the breakdown of muscle protein may be used for protein synthesis (Goldberg and Chang 1978). The availability of amino acids (high-quality protein supply) promotes protein synthesis and inhibits protein breakdown in muscle, as in other cells (Goldberg and Chang 1978). The release of amino acids from skeletal muscle reflects the catabolism of muscle protein and synthesis of some amino acids in this tissue (Teleni 1993). 
Essential amino acids are taken up by the body tissues from the blood at rates proportional to the amino acid requirements of the animal (Longenecker and Hause 1959). There is a relationship between dietary protein quality and free amino acid levels in blood (Longenecker and Hause 1959; Prieto et al. 1994), but some other factors, besides the concentration of amino acids in the ingested diet, such as endogenous nitrogen entering the digestive tract, may be expected to alter this relationship (Reitnour et al. 1970). However, normally plasma amino acid levels are dependent on the rate of absorption into the blood and their removal from the blood by the body tissues. The amino acids are removed from the blood at rates proportional to the animal's requirement for each amino acid, and deficiency of an amino acid in a diet causes a lowering of the concentration of this amino acid in the blood (Longenecker and Hause 1959; Burris et al. 1975). On the other hand, excess amino acids not needed for tissue synthesis accumulate in the blood. Elevated amino acid levels due to high-quality protein supplementation in adult and growing horses have been reported by Reitnour and Salsbury (1975), Reitnour (1978), and Saastamoinen and Koskinen (1993). Blood amino acid concentrations of foals must be interpreted critically because of the effect of age on amino acid content.

Lysine is the most intensively investigated amino acid in horses, and the detrimental effect of an inadequate supply of lysine on growth is well documented in the literature. Consequently, lysine has been concluded to be the most limiting amino acid for growth (e.g. Hintz et al. 1971; Ott et al. 1979, 1981). The current recommendations for the lysine intake of weanlings is $0.5-0.7 \%$ in feed (Meyer 1992; NRC 1989; FFT 1995), or 0.50-0.60 g/MJ DE (Hintz et al. 1971; Ott et al. 1979, 1981; Meyer 1992; NRC 1989; Saastamoinen and Koskinen 1993; Saastamoinen et al. 1994). For yearlings, the recommended lysine content is $0.5 \%$ (NRC 1989) or $0.4 \mathrm{~g} / \mathrm{MJ}$ DE (Meyer 1992). In the different recommendations, these figures correspond to approximately $35-40 \mathrm{~g} / \mathrm{d}$ for weanlings and yearlings expected to attain 500 to $550 \mathrm{~kg}$ mature weight. Schryver et al. (1987) found no significant improvement in growth rate when the lysine content was increased from 0.70 to $1.26 \%$.

Figures 1 and 2 illustrates the effect of dietary lysine content on muscle growth and weight gain. According to studies, weanlings are most sensitive to protein quality before the age of 8-10 months (Jordan and Myers 1972; Cymbaluk 1990a; Saastamoinen et al. 1994). Cymbaluk (1990a) reported that a $0.45 \%$ lysine content is adequate for (draft horse) weanlings after 10 months of age.

Graham et al. (1994) recently suggested threonine to be the second-limiting amino acid for yearling horses. In their study, threonine supplementation resulted in an increase in muscle gain owing to an assumed improvement in amino acid balance. They recommend a threonine content of $0.51 \%$ in concentrate, correspondig to $39.0 \mathrm{~g} / \mathrm{d}$ for yearlings. According to Finnish studies with weanlings (Tab. 2), $0.47-0.50 \%$ (approx. $32.3 \mathrm{~g} / \mathrm{d}$ ) together with an adequate lysine intake is deemed to be sufficient for weanlings.

Methionine, an important source of sulphur and methyl groups for muscle and connective tissue synthesis, if sup-

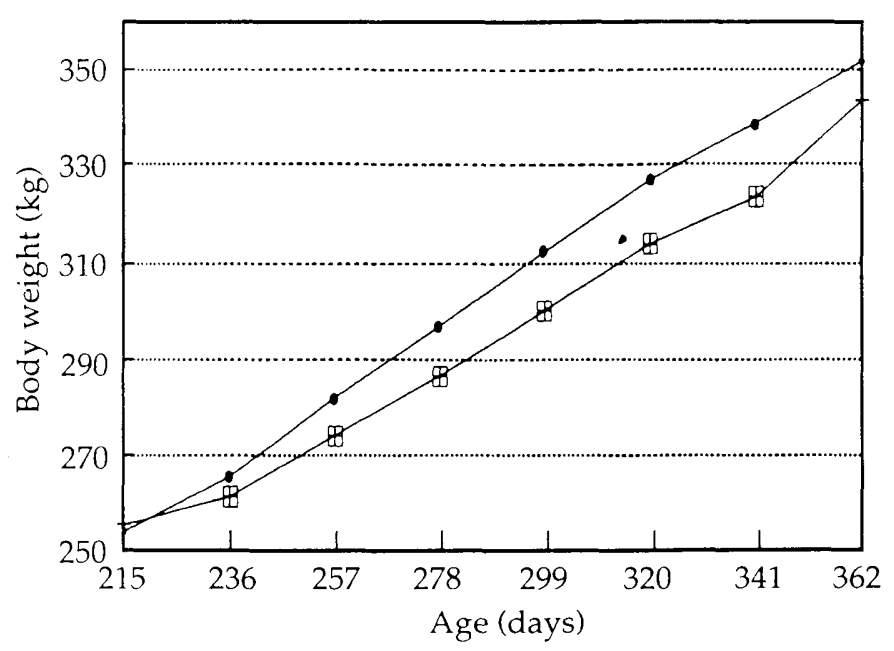

Fig. 1: Body weight growth of foals supplemented with high-( $42 \mathrm{~g}$ lysine $/ \mathrm{d}, 605 \mathrm{~g} \mathrm{DCP} / \mathrm{d}$ ) and poor-( $\square ; 31 \mathrm{~g}$ lysine/d, $584 \mathrm{~g} \mathrm{DCP} / \mathrm{d}$ ) quality protein. (Saastamoinen and Koskinen 1993)

Entwicklung der Körpergewichte von Fohlen mit der höchsten (•; $42 \mathrm{~g}$ Lysin/d, $605 \mathrm{~g}$ verd. Rohprotein/d) und der

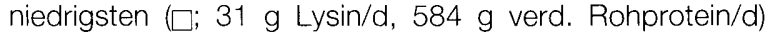
Proteinqualität

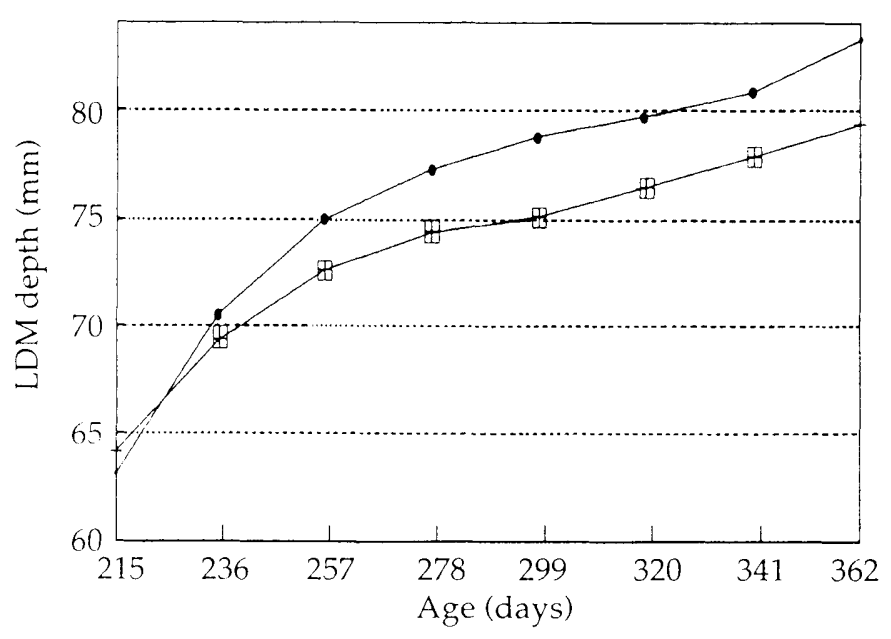

Fig. 2: Growth of longissimus dorsi muscle (LDM) in foals supplemented with high-(๑) $42 \mathrm{~g}$ lysine/d, $605 \mathrm{~g} \mathrm{DCP} / \mathrm{d})$ and poor-( $\square ; 31 \mathrm{~g}$ lysine/d, $584 \mathrm{~g} \mathrm{DCP} / \mathrm{d}$ ) quality protein. (Saastamoinen and Koskinen 1993)

Wachstum des Longissimus dorsi bei Fohlen mit der

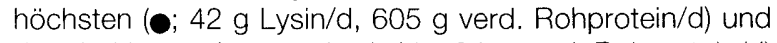
der niedrigsten ( $\square ; 31 \mathrm{~g}$ Lysin/d, $584 \mathrm{~g}$ verd. Rohprotein/d) Proteinqualität

plied in excess (>8.7 g/250 kg bwt), has been reported to inhibit calcium and phosphorus reabsorption (Glade et al. 1985). However, Saastamoinen et al. (1995) found no detrimental effects due to feeding $12-14 \mathrm{~g} / \mathrm{d}$ methionine to weanlings (aged 6-12 months, weighing about 260-360 kg). The average intake of $13.7 \mathrm{~g} / \mathrm{d}$ presented in Table 2 was deemed, therefore, to be suitable for weanlings, and involved no detrimental effects. On the other hand, the methionine content of mare's milk is low (Peltonen et al. 1980; Doreau et al. 1990), and methionine can not be suggested to be a limiting amino acid for growing horses. 
Tab. 2: Calculated intakes of nine essential amino acid $(\mathrm{g} / \mathrm{d})$ from different experimental diets and at the end of nursing period (see text) by weanlings.

Errechnete Aufnahme von 9 essentiellen Aminosäuren $(\mathrm{g} / \mathrm{d})$ aus verschiedenen Futtermitteln und am Ende der Säugezeit (siehe Text) bei Absetzern

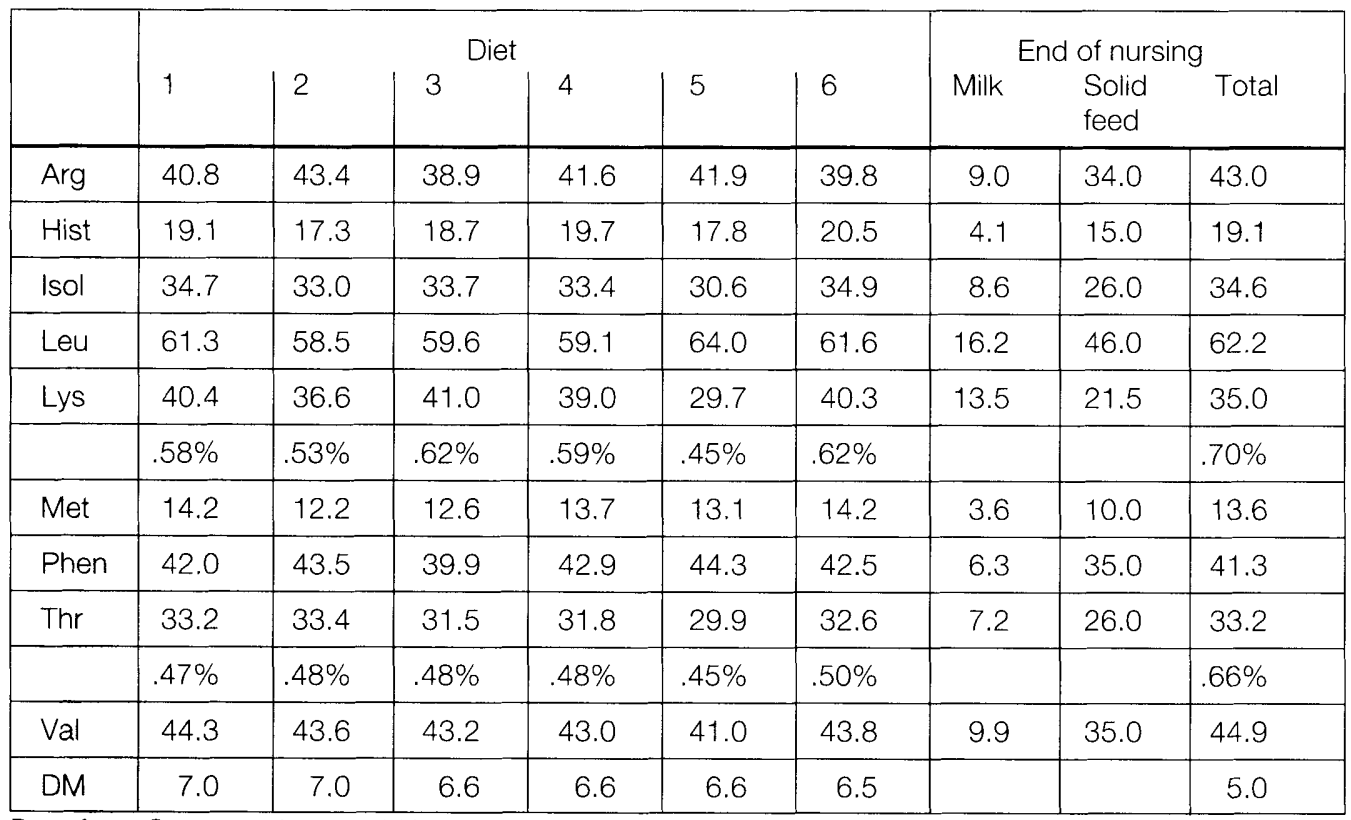

Data from Saastamoinen and Koskinen 1993; Saastamoinen et al. 1994; Saastamoinen et al. 1995

Data on other amino acids in foals are inadequate to establish any accurate recommendations. However, data concerning the intakes and blood levels of these amino acids (Tab. 2) may be indicative in this respect.

The intakes of nine essential amino acids by weanlings $(250 \mathrm{~kg})$ at the end of nursing period can be calculated, assuming a milk production of $10 \mathrm{~kg}$ with a protein content $1.8-1.9 \%$ (Gibbs et al. 1982; Burns et al. 1992), and the amino acid contents reported by Peltonen et al. (1980) and Doreau et al. (1990) at the end of lactation, as well as feed intake of foals as given by $D L G$ (1984) and NRC (1989), and using the amino acid contents given for typical solid feeds. E.g., the calculated lysine intake, approximately $35 \mathrm{~g} / \mathrm{d}$ with $13.5 \mathrm{~g}$ of it obtained from the milk, corresponds to the range of recommended levels for weanling foals. Also with the other amino acids the calculated intakes from the different protein supplements (not shown) correspond to the amount provided by milk. The amount of methionine provided from milk or from the protein supplement was low compared with that provided from solid feeds, and thus, compared with the total intake. Methionine may not, therefore, be a limiting amino acid for growing horses. All diets except the one containing $0.45 \%$ lysine and threonine (Diet 5 in Table 2) resulted in a growth rate that can be considered normal. In addition, foals on Diet 5 had decreased serum lysine and threonine levels (Saastamoinen and Koskinen 1993). Contents of tryptophan in mare's milk and in the diets (Tab. 2) and blood of weanlings have not been reported.

Balance and interactions between individual essential amino acids, as well as between the overall essential amino acids and protein may affect growth, and should, thus, be studied further. It has been reported that at the same level of lysine intake, the increment of dietary protein supply in pigs did not improve growth rate but, in fact, decreased it as a result of the catabolism of excess protein (Henry et al. 1992).

\section{Energy}

Weight gain can be stimulated to a greater extent than skeletal growth by energy intake (Thompson et al. 1988). The energy requirements for growth are important because energy intake may influence skeletal development and the incidence of developmental problems. Cymbaluk et al. (1990) reported that ad libitum fed (119 to $144 \%$ NRC1978) (77-94 MJ DE) foals had a higher occurence of conformational and muscoskeletal abnormalities than foals fed restricted diets. They also grew faster and had better DE efficiency. Also Savage et al. (1993) reported skeletal abnormalities in foals fed excess energy (129\% NRC-1989) (81 MJ DE). On the other hand, Thompson et al. (1988) found no detrimental effcets on growth or bone development due to high energy (159\% NRC-1978) (97.5 MJ DE) or protein (275\% NRC-1978) intakes, although there was a decrease in mineral deposition into bone.

The accelerated growth causing skeletal abnormalities is largely due to high intake of carbohydrates, which in turn causes hormonal changes stimulating a rapid growth of cartilage, resulting in improper cartilage maturation (Glade et al. 1984). Consequently, reducing the grain intake has been reported to be associated with fewer signs of skeletal abnormalities. Compensating carbohydrates in the diet by using fats as the energy source may have positive effects on bone formation in weanlings and yearlings (Davison et al. 1991; Saastamoinen et al. 1994). Furthermore, according to Donato et al. (1987), growing animals appear to uti- 
lize energy from dietary fat more efficiently than energy from dietary carbohydrates.

After weaning, the change to a new energy source may first decrease the energy intake, but later as intake increases, rapid compensatory growth may take place, which may result in or predispose to skeletal abnormalities. Thus, the correct dietary conditioning of foals prior to weaning is essential. Topliff et al. (1988) suggested that weanlings which are not genetically predisposed to severe developmental orthopedic problems are not affected by high levels of nutrition.

Weanlings (6-month-olds) and yearlings require 46 and 65 MJ DE per kg of gain, respectively (NRC 1989). American, Finnish, French and German recommendations for normal or optimal growth vary between 62-65 MJ DE/d for weanlings (from 6-7 to 12 months of age) and 66-79 $\mathrm{MJ} \mathrm{DE} / \mathrm{d}$ for yearlings, the highest recommendations being those of NRC (1989). The Danish recommendations (Staun 1990) are about 10 and $12 \%$ lower, respectively.

It has been recommended that foals and yearlings with skeletal abnormalities or at risk should not be overweight. The levels to which energy (and/or protein) intake in such cases should be reduced depend upon the individual case. Furthermore, height gain (length of bones) continues even after the restriction of body weight gain by decreased energy and protein intakes (Hintz 1992). Cymbaluk et al. (1989) concluded that if energy intake in young horses must be regulated, both concentrate and hay intake must be controlled. When restricting energy, the diets must, however, be supplemented to meet the need for other essential nutrients for growth. E.g., to maintain skeletal quality during rapid growth periods, protein intake has to be proportional to energy intake (Thompson et al. 1988).

If growth is reduced by restricted energy intake, this may result in compensatory growth at a later date. It has been reported that foals on restricted diets compensate for the growth loss while on pasture (Ellis and Lawrence 1978; MartinRosset 1983; Staun et al. 1987). French studies suggest that weanlings can be fed $20 \%$ below the current energy recommendations during the first winter, due to compensatory growth during the next summer (Bigot et al. 1989).

Temperatures have been reported to affect DE intake and requirement in growing horses. However, daily temperature fluctuations under cold conditions have very little effect on weight-scaled energy intake by full-fed horses; weight-scaled $\mathrm{DE}$ has been found to increase by $0.2 \%$ per $1{ }^{\circ} \mathrm{C}$ decrease in mean daily temperature below $0^{\circ} \mathrm{C}$ (Cymbaluk et al. 1989). Also the maintenance energy requirement was higher in cold-housed than in warm-housed foals (Cymbaluk 1990b). According to Canadian studies (Cymbaluk and Christison 1989; Cymbaluk et al. 1989), cold-reared weanling horses may need 3 to $6 \%$ more DE for growth and maintenance per $1^{\circ} \mathrm{C}$ in temperatures below $-10^{\circ} \mathrm{C}$. Thus, environmental factors, including precipitation and wind, must be considered in defining the DE requirements of growing horses housed outdoors without shelter. Furthermore, as regards foals in outdoor housing, energy recommendations should also be corrected for energy consumption for free moving. According to Orton et al. (1985), exercise in- creases the apparent digestiblity of energy and dry matter in young horses.

Yeast culture has been reported to increase fibre fermentability, which may increase the energy available for additional tissue growth (Glade and Biesik 1986). Energy efficiency may also be improved by substituting grain (carbohydrates) with fats in the diet of weanlings and yearlings (Davison et al. 1991; Saastamoinen et al. 1994).

\section{Conclusions}

Lysine and threonine have been indicated as the two first-limiting amino acids for growth, but data on other amino acids are insufficient for establishing any accurate recommendations. In addition to growth rate and age of the foal, the energy requirements for growth are influenced e.g. by the ambient temperature and the type of energy source. However, not enough is known about the effects of cold weather and cold conditions or of free moving on growth and energy demands.

Balance and interactions between different nutrients and nutrient sources may affect growth, and thus, call for additional study. Long-term research is also needed to establish more accurate recommendations. More research is also required on the use of growth and weight measures for the accurate monitoring of growth rate and for optimizing the nutrient intakes of growing horses.

\section{References}

Bigot, G., Trillaud-Geyl, C. and Martin-Rosset, W. (1989): Winterfeeding and growth of young horse sold at 42 months of age. Paper. 40th Ann. Meet. of EAAP.

Buffington, C. A. T., Knight, D. A., Kohn, C. W., Madigan, J. E. and Scaman, P. A. (1992): Effect of protein source in liquid formula diets on food intake, physiologic values, and growth of equine neonates. Am. J. Vet. Res. 53: 1941-1946.

Burns, H. D., Gibbs, P. G. and Potter, G. D. (1992): Milk-energy production by lactating mares. Equine Vet. Sci. 12: 118-120.

Burris, W. R., Bradley, N. W. and Boling, J. A. (1975): Growth and plasma amino acids of steers fed different nitrogen sources at restricted intake. J. Anim. Sci. 40: 714-719.

Cymbaluk, N. F. (1990a): Using canola meal in growing draft horse diets. Equine Pract. 12: 13-19.

Cymbaluk, N. F. (1990b): Cold housing effects on growth and nutrient demand of young horses. J. Anim. Sci. 68: 3152-3162.

Cymbaluk, N. F., Christison, G. I. and Leach, D. H. (1989): Energy uptake and utilization by limit- and ad libitum-fed growing horses. J. Anim. Sci. 67: 403-413.

Cymbaluk, N. F., Christison, G. I. and Leach, D. H. (1990): Longitudinal growth anakysis of horses following limited and ad libitum feeding. Equine Vet. J. 22: 198-204.

Davison, K. E., Potter, P. G., Evans, J. W., Greene, L. W., Hargis, P. S., Corn, C. D. and Webb, S.P. (1991): Growth, nutrient utilization, radiographic bone characteristics and postprandial thyroid hormone concentrations in weanling horses fed added dietary fat. Equine Vet. Sci. 11: 119-125.

DLG (1984): DLG-Futterwerttabellen für Pferde. 2. Auflage. Frankfurt am Main: DLG-Verlag. pp. 122.

Donato, K. A. (1987): Efficiency and utilization of various energy sources for growth. Am. J. Clin. Nutr. 45: 164-167.

Doreau, M., Boulot, S., Barlet, J.-P. and Patureau-Mirand, P. (1990): Yield and composition of milk from lactating mares: effect of lactation stage and individual differences. J. Dairy Res. 57: 449-454. 
Ellis, R. N. W. and Lawrence, T. L. J. (1978): Energy under-nutrition in the weanling filly foal. I. Effects on subsequent live-weight gains and onset of oestrus. Br. Vet. J. 134: 205-211.

FFT (1995): Feed tables and Feeding recommendations, (in Finnish). Helsinki: University of Helsinki, Plant Production Inspection Centre, Agricultural Research Centre. pp. 99.

Gibbs, P. G., Potter, G. D., Blake, R. W. and McMullan, W. C. (1982): Milk production of Quarter horse mares during 150 days of lactation. J. Anim. Sci. 54: 496-499.

Glade, M. J., Gupta, S. and Reimers, T. J. (1984): Hormonal responses to high and low planes of nutrition in weanling Thoroughbreds. J. Anim. Sci. 59: 658-665.

Glade, M. J., Beller, D., Bergen, J., Berry, D., Blonder, E., Bradley, J., Cupelo, M. and Dallas, J. (1985): Dietary protein in excess of requirements inhibits renal calcium and phophorus reabsorption in young horses. Nutr. Rep. Int. 31: 649-659.

Glade, M. J. and Biesik, L. M. (1986): Enhanced nitrogen retention in yearling horses supplemented with yeast culture. J. Anim. Sci. 62: 1635-1640.

Glade, M. J. and Sist, M. D. (1990): Supplemental yeast culture alters the plasma amino acid profiles of nursling and weanling foals. Equine Vet. Sci. 10: 369-379.

Goldberg, A. L. and Chang, T. W. (1978): Regulation and significance of amino acid metabolism in skeletal muscle. Federation Proc. 37: 2301-2307

Goodbee, R. G. and Slade, L. M. (1981): The effect of urea or soybean meal on the growth and protein status of young horses. J. Anim. Sci. 53: 670-676.

Graham, P. M., Ott, E. A., Brendemuhl, J. H. and TenBroek, S. H. (1994): The effect of supplemental lysine and threonine on growth and development of yearling horses. J. Anim. Sci. 72: 380-386.

Henry, $Y$, Colleaux, Y. and Seve, B. (1992): Effects of dietary level of lysine and of level and source of protein on feed intake, growth performance, and plasma amino acid pattern in the finishing pig. J. Anim. Sci. 70: 188-195.

Hintz, H. F. (1992): Effect of energy and protein deprivation on bodyweight and height gains of young horses. Equine Pract. 14: 7-8.

Hintz, H. F., Schryver, H. F. and Lowe, J. E. (1971): Comparison of a blend of milk products and linseed meal as protein supplements for young growing horses. J. Anim. Sci. 33: 1274-1277.

Imbeah, M. and Sauer, W. C. (1991): The effect of dietary level of fat on amino acid digestibilities in soybean meal and canola meal and on rate of passage in growing pigs. Livest. Prod. Sci. 29: 227-239.

Jordan, R. M. and Myers, V. (1972): Effect of protein levels on the growth of weanling and yearling ponies. J. Anim. Sci. 34: 578-581.

Kennedy, L. G. and Hershberger, T. V. (1974): Protein quality for the nonruminant herbivore. J. Anim. Sci. 39: 506-511.

Li, S. and Sauer, W. C. (1994): The effect of dietary fat content on amino acid digestibility in young pigs. J. Anim. Sci. 72: 1737-1743.

Longenecker, J. B. and Hause, N. L. (1959): Relationship between plasma amino acids and composition of the ingested protein. Arch. of Biochem. a. Biophys. 84: 46-59.

Martin-Rosset, W. (1983): Husbandry and feeding of heavy breed and saddle young horse. Paper. 33rd Ann. Meet. of EAAP.

Martin-Rosset, W. Ed. (1990): L'alimentation des chevaux. Paris: INRA. pp. 232.

McDonald, P., Edwards, R. A. and Greehalgh, J. F. D. (1988): Animal nutrition. 4th ed. New York: Longman Scientific \& Tecnical. pp. 42-57.

Mello, J. P. F. (1993): Amino acid supplementation of cereal-based diets for non-ruminants. Anim. Feed. Sci. a Technol. 45: 1-18.

Meyer, H. (1983): Protein metabolism and protein requirement in horses. Comp.IVth int. Symp. Protein metabolism and nutrition, pp.343-364

Meyer, H. (1992): Pferdefütterung. 2. Aufl. Berlin u. Hamburg: Paul Parey. pp. 223.

NRC (1989): Nutrient requirements of horses. 5th Ed. Washington D.C.: National Academic Press. pp. 100.

Orton, R. K., Hume, I. D. and Leng. R. A. (1985): Effects of level of dietary protein and exercise on growth rates of horses. Equine Vet. J. $17: 381-385$.

Ott, E. A., Asquith, R. L., Feaster, J. P. and Martin, F. G. (1979): Influence of protein level and quality on the growth and development of yearling foals. J. Anim. Sci. 49: 620-627.
Ott, E. A., Asquith, R. L. and Feaster, J. P. (1981): Lysine supplementation of diets for yearling horses. J. Anim. Sci. 53: 1496-1503.

Peltonen, T., Kossila, V., Antila, V. and Huida, L. (1980): Effects of protein supplement on milk composition of mares and growth rate of their foals. Paper. 31st Ann. Meet of EAAP.

Prieto, C., Aguilera. J. F., Lachica, M., Fernandez-Figares, I., Perez, L., Nieto, R. and Ferrando, G. (1994): The use of plasma free amino acids for predicting the limiting amino acids in diets for chickens. Anim. Feed. Sci. a. Technol. 47: 151-164.

Reitnour, C. M. (1978): Response to dietary protein in ponies. Equine Vet. J. 10: 65-68.

Reitnour, C. M., Baker, J. P., Mitchell, G. E. jr, Little, C. O. and Kratzer, D. D. (1970): Amino acids in equine cecal contents, cecal bacteria and serum. J. Nutr. 100: 349-354.

Reitnour, C. M. and Salsbury, R. L. (1975): Effect of oral or caecal administration of protein supplements on equine plasma amino acids. Br. Vet. J. 131: 466-473.

Reitnour, C. M. and Salsbury, R. L. (1976): Utilization of proteins by the equine species. Am. J. Vet. Res. 37: 1065-1067.

Saastamoinen, M. T. and Koskinen, E. (1993): Influence of quality of dietary protein supplement and anabolic steroids on muscular and skeletal growth of foals. Anim. Prod. 56: 135-144.

Saastamoinen, M. T., Hyypp, S. and Huovinen. K. (1994): Effect of dietary fat supplementation and energy-to-protein ratio on growth and blood metabolites of weanling foals. J. Anim. Physiol. a. Anim. Nutr. 71: 179-188.

Saastamoinen, M. T. Hyypp, S. and Nousiainen, J. (1995): Growth and serum amino acids and blood metabolites in weanling foals. Paper. 46th Ann. Meet. of EAAP.

Savage, C. J., McCarthy, R. N. and Jeffcott, L. B. (1993): Effects of dietary energy and protein on induction of dyschondroplasia in foals. Equine Vet. J. 16: 74-79.

Schryver, H. F., Meakim, D. W., Lowe, J. E., Williams, J., Soderholm, L. V. and Hintz, H. F. (1987): Growth and calcium metabolism in horses fed varying levels of protein. Equine Vet. J. 19: 280-287.

Slade, L. M., Robinson, D. W. and Casey, K. E. (1970): Nitrogen metabolism in non-ruminant herbivores. I. The influence of nonprotein nitrogen and protein quality on nitrogen retention of adult mares. J. Anim. Sci. 30: 753-760.

Smith, R. E. and Scott, H. M. (1965): Use of free amino acid concentration in blood plasma in evaluating the amino acid adequacy of intact proteins for chick growth. J. Nutr. 86: 45-50.

Staun, H. (1990): Energy and nitrogen systems used in northern Europe for estimating and expressing value of feedstuffs in horse. Paper. 41st An.. Meet. of EAAP.

Staun, H., Eriksen, L., Nielsen, K., Snnichsen, H. V., Ronne, J. F., Schambye, P., Henckel, P. and Fraehr, E. (1987): Influence of feeding intensity on the development of the young growing horse until 18 months of age. Beretning fra Statens Hudyrbrugsforsog 630. pp. 79.

Teleni, E. (1993): Catabolism and synthesis of amino acids in skeletal muscle: Their significance in monogastric mammals and ruminants. Aust. J. Sgric. Res. 44: 443-461.

Thompson, K. N., Jackson, S. G. and Baker, J. P. (1988): The influence of high planes of nutrition on skeletal growth and development of weanling horses. J. Anim. Sci. 66: 2459-2467.

Topliff, D. R., Boren, S. R., Freeman, D. W., Bahr, R. J. and Wagner, $D$. G. (1988): Growth of weanling Quarter horses fed varying energy and protein levels. Equine Vet. Sci. 8: 371-375.

Yoakam, S. C., Kirkham, W. W. and Beeson, W. M. (1978): Effect of protein level on growth in young ponies. J. Anim. Sci. 46: 983-991.

\section{Markku T. Saastamoinen}

Agricultural Research Centre

Equine Research

FIN-32199 Ypäjä

Finland 